Nowoczesne Systemy Zarządzania

Zeszyt 12 (2017), nr 4 (październik-grudzień)

ISSN 1896-9380, s. 63-75

Modern Management Systems

Volume 12 (2017), No. 4 (October-December)

ISSN 1896-9380, pp. 63-75
Instytut Organizacji i Zarządzania

Wydział Cybernetyki

Wojskowa Akademia Techniczna

w Warszawie

Institute of Organization and Management

Faculty of Cybernetics

Military University of Technology

\title{
Rozwój kapitału ludzkiego w Siłach Zbrojnych RP w perspektywie kluczowych kompetencji organizacji
}

\section{Development of human capital in the armed forces of the republic in the perspective of key competences of the organization}

\author{
Marzena Piotrowska-Trybull \\ Akademia Sztuki Wojennej \\ Maria Jabłońska-Wołoszyn \\ Akademia Sztuki Wojennej
}

Abstrakt. Celem artykułu jest przedstawienie koncepcji badań nad zastosowaniem kluczowych kompetencji organizacyjnych do analizy zadań strategicznych w obszarze zarządzania kapitałem ludzkim w Siłach Zbrojnych RP. Autorki prezentują ocenę zarządzania kapitałem ludzkim w systemie bezpieczeństwa narodowego RP i na poziomie strategicznym identyfikują kluczowe obszary rozwoju.

Słowa kluczowe: kapitał ludzki, zarządzanie kompetencjami, Siły Zbrojne RP, organizacje publiczne.

Abstract: The subject of the article is to present the concept of research on using the key organizational competence to analyze the strategic tasks in the area of human capital management in the armed forces of the Republic of Poland (RP). The authors present the evaluation of the human capital management in the national security system of RP and at the strategic level identify the key areas for development. Keywords: human capital, competence management, the armed forces of RP, public organizations.

\section{Wstęp}

Siły zbrojne są organizacją publiczną będącą częścią składową sektora publicznego. W ich skład wchodzą jednostki wojskowe rozmieszczone na terytorium państwa. Siły zbrojne, podobnie jak administrację publiczną, można scharakteryzować w oparciu o następujące cechy: działanie w imieniu i na rachunek państwa, działanie 
na podstawie prawa i tylko w jego granicach, działanie w interesie publicznym oraz w ramach przyznanej kompetencji, bezosobowy oraz władczy charakter działań w organizacjach, dominacja więzi hierarchicznych, realizacja zadań przez odpowiednio wyszkolone kadry, ciągłość działań. Cechy te w pewnym stopniu mogą ograniczać wprowadzanie innowacji do organizacji, które z założenia są interakcyjne, multidyscyplinarne, zintegrowane, wsparte procesem uczenia się, a także procesem kreatywnej destrukcji. Jednak wyzwania i cechy otoczenia, w którym funkcjonują organizacje, w tym: zmienność, złożoność i dynamika, wzmagają potrzebę strukturyzacji działań w organizacjach publicznych, jak również wzrost ich efektywności, warunkowany m.in. poziomem innowacyjności.

Mimo że siły zbrojne jako organizacja publiczna wykazują różnice w stosunku do organizacji biznesowych (przedsiębiorstw), dotyczące m.in. (Bednaczyk, 2001, [za:] Kożuch, 2003, s. 44): przedmiotu transakcji z otoczeniem (dobra publiczne versus dobra prywatne); charakteru celów działania (publicznych versus komercyjnych); źródeł władzy (własność publiczna, prywatna oraz mandat polityczny, społeczny, członka grupy interesów), to część rozwiązań wdrażanych i upowszechnianych w przedsiębiorstwach może stanowić wzorzec dla ich działań. Ewolucja form zorganizowanego działania w organizacjach publicznych, od administrowania do zarządzania publicznego (Nowakowska-Krystman, Piotrowska-Trybull 2016, s. 130145), pozwala koncentrować się na współczesnych wyróżnikach zarządzania organizacjami publicznymi, a mianowicie: innowacjach i przedsiębiorczości wewnętrznej, myśleniu strategicznym i działaniu, a także zaawansowanych technologiach informacyjnych, które stanowią krytyczne obszary dla ich efektywności. Dążąc do podniesienia efektywności procesów w organizacjach publicznych, należy mieć na uwadze, że organizacje te dostarczają społeczeństwu dóbr publicznych sensu largo, które obejmują klasyczne dobra publiczne oraz dobra społeczne (oświata, opieka zdrowotna). Obrona narodowa jest zaliczana do tzw. czystych dóbr publicznych. Jest ona dostarczana na zasadach powszechnej dostępności, co oznacza, że korzystanie z danego dobra przez część społeczeństwa nie ogranicza możliwości korzystania $\mathrm{z}$ tego dobra także przez inne osoby (Black, 2008, s. 69). Jednocześnie produkcja oraz konsumpcja tego typu dóbr nie odbywa się na zasadach rynkowych i jest finansowana z budżetu. Obrona narodowa umożliwia zaspokojenie jednej z najważniejszych potrzeb człowieka - bezpieczeństwa, stanowiącego kategorię uniwersalną, ponadczasową i ponadnarodową (Kuriata, 2016, s. 13). Warto podkreślić, że współczesne wyzwania w zakresie tworzenia i dostarczania usług publicznych powinny sprostać kryteriom efektywności, skuteczności oraz sprawiedliwości. 


\section{Podstawy teoretyczne badania nad innowacyjnymi rozwiązaniami zarządzania kapitałem ludzkim w Silach Zbrojnych}

Z perspektywy dorobku nauki o zarządzaniu można wymienić różne określenia, które stosuje się zamiennie w celu opisaniu ludzi jako zasobu, aktywu lub kapitału organizacji. Odnosząc się do szeregu definicji pojęcia kapitał ludzki, można zauważyć, że bywa zamiennie stosowane jako metafora odnosząca się do wartości ludzi w organizacji, jako nurt badań z zakresu zarządzania zasobami ludzkimi oraz jako współczesna koncepcja zarządzania (Król, Ludwiczyński, 2006, s. 116-117). Pojemność pojęcia kapitał ludzki wynika z przyjmowania różnych perspektyw służących do jego opisu i umożliwiających odróżnienie „kapitału ludzkiego” od pojęcia „zasób ludzki” - organizacja posiadająca największą liczbę zasobów ludzkich nie musi mieć największego kapitału ludzkiego (Samul, 2013, s. 198-200). W związku z tym należy przyjąć następujące założenie: koncepcja kapitału ludzkiego podkreśla ocenę efektów zarządzania pracownikami w osiąganiu celów strategicznych przez organizację.

Kolejnym pojęciem wymagającym zdefiniowania jest innowacja, potocznie rozumiana jako każda nowość i oznaczająca zmianę w organizacji. Jak podkreśla J. Penc: „Innowacje oznaczają zmianę, ale nie każda zmiana jest innowacją (...). Może być ona zmianą reaktywną powielającą już istniejące rozwiązania, może też przekształcać je i lepiej przystosowywać do wymagań otoczenia" (Penc, Warszawa 1999, s. 141). Innowacje są postrzegane jako warunek funkcjonowania i rozwoju przedsiębiorstw w gospodarce konkurencyjnej (Baruk, 2006, s. 20). Utożsamia się je z: nowymi produktami, nowymi metodami produkcji, otwarciem nowego rynku, zdobyciem nowego źródła surowców lub półfabrykatów, przeprowadzeniem nowej organizacji jakiegoś przemysłu (Schumpeter, 1960, s. 104). Natomiast „Innowacyjność w zakresie zarządzania zasobami ludzkimi definiować można jako ideę, politykę, program, praktykę lub system odnoszący się do funkcji zarządzania zasobami ludzkimi, pod warunkiem że są one nowe dla adaptującej ją organizacji”" (Kossek, 1989, s. 263-281), (Staniewski, 2011, s. 195-210).

W kontekście rodzajów innowacji wyróżnionych przez R.F. Griffina: radykalnych, stopniowych, technicznych, kierowniczych, produktowych i procesowych (Griffin, 2002, s. 661-663), nowe rozwiązania w obszarze zasobów ludzkich wdrażane w organizacjach posiadają cechy innowacji kierowniczych oraz procesowych. Ponadto wśród cech innowacji wskazuje się na ich: zależność nie tylko od technologicznego know-how, ale również wiedzy, doświadczenia i relacji z innymi podmiotami, interakcyjność, multidyscyplinarność, zlokalizowanie, wysokie koszty, ryzyko, zintegrowanie, proces uczenia się, wymiar społeczny, proces kreatywnej destrukcji, kulturowe źródła pochodzenia w procesie historycznym (Stawasz, 29.11.2016). Cechy te $\mathrm{w}$ różnym zakresie można zidentyfikować $\mathrm{w}$ procesie tworzenia i adaptacji innowacyjnych rozwiązań w obszarze zasobów ludzkich w organizacjach. 
Biorąc pod uwagę definicję innowacyjności przyjmowaną na gruncie zarządzania zasobami ludzkimi (ZZL) prezentowaną powyżej, założono, że innowacyjne rozwiązania w zakresie zarządzania kapitałem ludzkim w Siłach Zbrojnych RP wynikają z potrzeby osiągania celów strategicznych w zakresie bezpieczeństwa i obronności państwa, co koresponduje z wskazanymi obszarami krytycznej efektywności w zarządzaniu organizacjami publicznymi.

Jedną z najbardziej popularnych koncepcji zarządzania w praktyce jest zarządzanie strategiczne. Jego podstawą jest „myślenie strategiczne oparte na analizie i doświadczeniu, uznające zarówno dziedzictwo przeszłości, jak i tempo zmian wraz z koncepcją przyszłości" (Allaire, 2000, s. 10). Na dużym poziomie ogólności koncepcja zarządzania strategicznego kładzie nacisk na działalność organizacji w kontekście zmian w otoczeniu i szukanie w nim możliwości budowania kapitału organizacji w perspektywie długookresowej: przyszłe sytuacje a antycypowane kierunki rozwoju organizacji. Działania w perspektywie strategicznej powinny dotyczyć wszystkich aspektów kapitału organizacji, zarówno materialnego, jak i niematerialnego (rys. 1), ukierunkowanego na jej sukces.

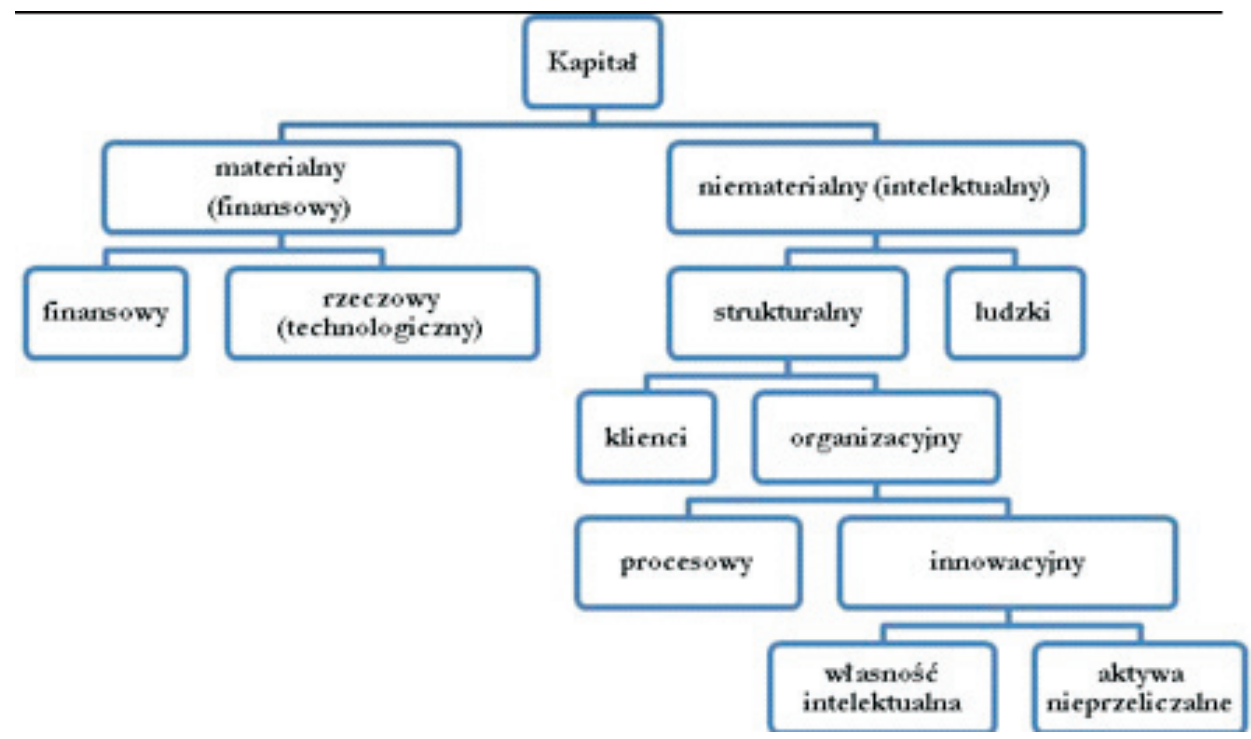

Rys. 1. Kapitał ludzki w modelu kapitału firmy według Skandii AFS

Źródło: L. Edvinsson, M. Malone, Intellectual Capital: The Proven Way to Establish Your Company's Real Value By Measuring Its Hidden Brainpower, Piatkus, London 1997

Rozwój koncepcji zarządzania strategicznego z perspektywy praktyki zarządczej wskazuje, że sukces organizacji przestał być wyłącznie funkcją umiejętnego lokowania i wykorzystywania kapitału. Teoretycy i praktycy podkreślają, że budowanie 
przewagi konkurencyjnej jest możliwe dzięki unikalnym rozwiązaniom, które $\mathrm{w}$ danym przedsiębiorstwie są uznawane za zasób strategiczny. Jednym $\mathrm{z}$ takich rozwiązań jest wymiar kompetencji organizacji (Bratnicki, 2000, s. 7). Pojęcie kompetencji organizacji wprowadzili G. Hamel i C.K. Prahalad (Hamel, 1989, nr 3), odnosząc je do ambicji, sposobów myślenia i potrzeby bycia najlepszym. Ich zdaniem kompetencje te wyznaczają nowe wyzwania dla procesu tworzenia odpowiednich warunków dla pracowników, determinujących osiąganie celów organizacji. Zdaniem Hamela i Prahalada (Hamel, 1990, nr 3) kompetencje organizacyjne są obszarami wiedzy i doświadczenia charakterystycznymi dla danej firmy, na które składają się elementy ściśle ze sobą powiązane.

Podsumowując, jeśli założymy, że perspektywa organizacyjna zarządzania kapitałem ludzkim odnosi się do powiązania właściwości (kompetencje indywidualne) pracowników ze strategią i właściwościami organizacji (kompetencje organizacyjne), to szukanie rozwiązań innowacyjnych powinno sprowadzić się do zidentyfikowania wyróżników kompetencji organizacyjnych w zakresie kapitału ludzkiego Sił Zbrojnych RP.

\section{Praktyczny wymiar zarządzania kapitałem ludzkim Sił Zbrojnych RP - diagnoza obszarów dla innowacji}

Do określenia zmian w koncepcji kapitału ludzkiego w Siłach Zbrojnych RP niezbędna stała się analiza stanu faktycznego w zakresie rozwiązań realizowanych w ramach funkcji personalnej, odnoszących się bezpośrednio do możliwości osiągania celów strategicznych przez System Bezpieczeństwa Narodowego RP. W związku z tym przedmiotem zainteresowania stała się przede wszystkim problematyka kapitału ludzkiego analizowana w perspektywie wyzwań zidentyfikowanych przez państwo polskie, określonych w dokumentach strategicznych i operacyjnych, a dotyczących Sił Zbrojnych RP. Celem prowadzonych badań jest identyfikacja najważniejszych atrybutów kapitału ludzkiego Sił Zbrojnych RP oraz wypracowanie wniosków dotyczących możliwości wprowadzania innowacyjnych rozwiązań w zakresie oddziaływania na kluczowe kompetencje kapitału ludzkiego w wojsku. Osiągnięcie tak sformułowanego celu było możliwe dzięki zastosowaniu techniki desk research służącej do analizy danych zastanych dotyczących wyzwań strategicznych w zakresie kapitału ludzkiego, która w przyjętym postępowaniu badawczym poprzedziła badania prowadzone z wykorzystaniem metody badań sondażowych (umożliwiającej zidentyfikowanie kompetencji kluczowych, które w opinii badanych w największej mierze przyczyniają się do osiągnięcia założonych celów, a także określenia luki kompetencyjnej w tym obszarze).

Jako punkt odniesienia wybrano opracowanie A.B. Escrig-Teny i J.C. Bou-Llousara (Mazurkiewicz, Frączek, 2011, s. 98), w którym autorzy zaproponowali 
uniwersalny zestaw kluczowych kompetencji organizacji (modelowe kompetencje stanowiące benchmark dla organizacji):

1. „przywództwo - kompetencje w tym obszarze obejmują umiejętność przełożonych do artykułowania i komunikowania wizji oraz strategii przedsiębiorstwa, a także wspierania podwładnych w ich realizacji;

2. wykorzystanie otoczenia przedsiębiorstwa - koncentracja na kliencie, dostarczanie informacji o otoczeniu;

3. rozwijanie know-how pracowników - stwarzanie warunków sprzyjających kreatywności pracowników, co równocześnie wzbogaca ich pracę;

4. umiejętność współpracy zewnętrznej - tworzenie partnerskich relacjiz klientami i dostawcami;

5. tworzenie „zespołowego umysłu” - podejmowanie działań sprzyjających pracy zespołowej;

6. zaangażowanie na rzecz przedsiębiorstwa - realizowanie przedsięwzięć sprzyjających identyfikacji z celami i wartościami uznawanymi w przedsiębiorstwie za ważne;

7. stymulowanie procesu uczenia się przedsiębiorstwa - działanie zgodnie z ustrukturyzowanymi procesami rozwiązywania problemów i stwarzanie warunków do pracy zespołowej, która sprzyja uczeniu się przedsiębiorstwa;

8. elastyczność w projektowaniu nowych produktów, skracanie czasu wykonywania poszczególnych operacji;

9. budowanie reputacji przedsiębiorstwa - dbałość o pozytywne relacje z klientami, dostawcami, kontrahentami i pracownikami, a także stwarzanie warunków do osiągania wysokiej efektywności”.

Następnie dokonano przeglądu dokumentacji strategicznej RP, która bezpośrednio lub pośrednio dotyczy funkcjonowania Sił Zbrojnych RP, tj.:

- Strategia rozwoju systemu bezpieczeństwa narodowego Rzeczypospolitej Polskiej - przyjęta uchwałą Rady Ministrów z dnia 9 kwietnia 2013 r.;

- Strategia bezpieczeństwa narodowego Rzeczypospolitej Polskiej - przyjęta przez Radę Ministrów w 2014 r.

Szczegółowe zapisy zawarte we wskazanych dokumentach strategicznych stanowiły podstawę do opracowania wytycznych do zdefiniowania kluczowych kompetencji sił zbrojnych w zakresie kapitału ludzkiego. Podczas analizy szukano przede wszystkim zapisów - słów kluczowych, które bezpośrednio (kapitał ludzki, zasób ludzki) i pośrednio (kontekst przedmiotowy dotyczący procesu personalnego) odnosiły się do kapitału ludzkiego sił zbrojnych. Po zebraniu materiału i jego analizie przyporządkowano poszczególne kluczowe kompetencje (benchmark) do wyznaczników kapitału ludzkiego z dokumentacji strategicznej ${ }^{1}$. Rezultaty otrzymane w wyniku przyjętej procedury zaprezentowano w tabeli 1 .

Na podstawie własnej wiedzy eksperckiej autora, pozyskanej w trakcie realizacji warsztatów strategicznych i paneli kompetencyjnych zarówno w organizacjach biznesowych, jak i publicznych. 
Tabela 1. Wyróżniki strategiczne kapitału ludzkiego Sił Zbrojnych RP a „modelowe" kluczowe kompetencje

\begin{tabular}{|c|c|}
\hline $\begin{array}{c}\text { Numer } \\
\text { kluczowej } \\
\text { kompetencji }\end{array}$ & $\begin{array}{l}\text { Wyróżniki strategiczne odnoszące się do kapitału ludzkiego } \\
\text { w Strategii bezpieczeństwa narodowego Rzeczypospolitej Polskiej }\end{array}$ \\
\hline 6,9 & $\begin{array}{l}\text { Cele strategiczne w dziedzinie bezpieczeństwa: } \\
\text { „Zapewnienie bezpiecznych warunków rozwoju kapitału ludzkiego i społecznego oraz } \\
\text { innowacyjności, efektywności i konkurencyjności gospodarki, a także stabilności } \\
\text { finansowej państwa” (s. 11-12). }\end{array}$ \\
\hline 3,9 & $\begin{array}{l}\text { Potencjał społeczny, w tym kapitał ludzki, jest ważnym czynnikiem warunkującym } \\
\text { wzrost gospodarki narodowej, sprawność państwa, aktywność społeczeństwa obywa- } \\
\text { telskiego oraz ogólną poprawę jakości życia obywateli. } \\
\text { Nowoczesny system edukacji publicznej i szkolnictwa wyższego, a także upowszech- } \\
\text { nienie różnych form uczenia się przez całe życie służą wykształceniu społeczeństwa } \\
\text { aktywnego i mobilnego. Istotnym elementem rozwoju kapitału ludzkiego i społecznego } \\
\text { jest edukacja na rzecz bezpieczeństwa (s. 14). }\end{array}$ \\
\hline 3,8 & $\begin{array}{l}\text { Rozwojowi zdolności operacyjnych Sił Zbrojnych RP musi towarzyszyć podnoszenie } \\
\text { poziomu wyszkolenia i umiejętności profesjonalnego wykorzystywania zaawansowanej } \\
\text { techniki wojskowej, w tym narzędzi informatycznych. Konieczne będzie rozwijanie } \\
\text { w Siłach Zbrojnych RP zdolności do działań w cyberprzestrzeni, w tym stworzenie } \\
\text { mechanizmów cyberobrony i wzmocnienie przeznaczonych dla niej jednostek. Istotne } \\
\text { jest też rozwijanie narodowych zdolności w zakresie kryptologii i nabycie pełnych } \\
\text { zdolności w dziedzinie wytwarzania narodowych rozwiązań kryptograficznych w celu } \\
\text { zapewnienia odpowiedniego poziomu bezpieczeństwa systemów teleinformatycznych. } \\
\text { Osiąganie kompetencji Sił Zbrojnych RP w zakresie kryptologii powinno wynikać } \\
\text { z jednolitej polityki kryptologicznej i jest czynnikiem krytycznym w zapewnieniu } \\
\text { bezpieczeństwa teleinformatycznego (s. 46). }\end{array}$ \\
\hline 7,9 & $\begin{array}{l}\text { Zmiany w systemie szkolnictwa wojskowego powinny zmierzać do jego konsolidacji oraz } \\
\text { być zorientowane na poprawę efektywności szkolenia i prowadzenie badań naukowych } \\
\text { na potrzeby bezpieczeństwa i obronności państwa, poprawę wydatkowania środków pu- } \\
\text { blicznych, a także wpisanie obszaru szkolenia i doskonalenia zawodowego szeregowych } \\
\text { i podoficerów w krajowy system edukacji oparty na Polskiej Ramie Kwalifikacji. Istotne } \\
\text { jest usprawnienie systemu wojskowej opieki medycznej, ukierunkowanej na odbudowę } \\
\text { korpusu medycznego oraz modernizację polowej techniki medycznej (s. 46-47). }\end{array}$ \\
\hline $3,4,5,8$ & $\begin{array}{l}\text { Priorytetowo w rozwoju służb specjalnych należy traktować jakość kadr tych służb oraz } \\
\text { wdrożenie najnowszych zinformatyzowanych technicznych systemów wywiadowczych } \\
\text { i kontrwywiadowczych. Wojskowe służby specjalne powinny być silniej zintegrowane } \\
\text { z resortem obrony narodowej (s. 47). }\end{array}$ \\
\hline 4,9 & $\begin{array}{l}\text { Cele powiązania Strategii rozwoju kapitału ludzkiego ze Strategia rozwoju bezpieczeń- } \\
\text { stwa narodowego RP: } \\
\text { • } \quad \text { umocnienie zdolności państwa do obrony; } \\
\text { • } \quad \text { zwiększenie integracji polityki publicznej z polityką bezpieczeństwa (s. 6). }\end{array}$ \\
\hline $3,4,9$ & $\begin{array}{l}\text { Analiza SWOT systemu bezpieczeństwa narodowego a kapitał ludzki - mocne strony: } \\
\text { - } \quad \text { konsekwentna budowa profesjonalnych sił zbrojnych, w tym stworzenie Naro- } \\
\text { dowych Sił Rezerwowych; } \\
\text { - dobrze wykształcona i wyszkolona kadra sił zbrojnych, zdobywająca doświad- } \\
\text { czenie podczas operacji poza granicami kraju i służby w międzynarodowych } \\
\text { strukturach wojskowych (s. } 31 \text { ). }\end{array}$ \\
\hline
\end{tabular}




\begin{tabular}{|c|c|}
\hline $\begin{array}{l}\text { Numer } \\
\text { kluczowej } \\
\text { kompetencji }\end{array}$ & $\begin{array}{l}\text { Wyróżniki strategiczne odnoszące się do kapitału ludzkiego } \\
\text { w Strategii bezpieczeństwa narodowego Rzeczypospolitej Polskiej }\end{array}$ \\
\hline $2,3,7$ & $\begin{array}{l}\text { W perspektywie długookresowej Polska będzie posiadać sprawne, mobilne i interope- } \\
\text { racyjne Siły Zbrojne, które w sposób systemowy i proaktywny (wyprzedzający) będą } \\
\text { dostosowywały zdolności operacyjne do zmian zachodzących w otoczeniu. Odbywać } \\
\text { się to będzie poprzez poszukiwanie i wprowadzanie innowacyjnych zmian oraz wyko- } \\
\text { rzystanie nabytej wiedzy i doświadczeń. Priorytetem transformacji Sił Zbrojnych RP } \\
\text { w horyzoncie strategii będzie podniesienie poziomu ich zdolności operacyjnych oraz } \\
\text { utrzymanie sił przygotowanych do reagowania na obecne oraz nowe i nieprzewidywalne } \\
\text { zagrożenia. Istotnym elementem przygotowania Sił Zbrojnych RP do przeciwdziałania } \\
\text { współczesnym zagrożeniom będzie podniesienie poziomu wyszkolenia wojskowego } \\
\text { i ogólnego żołnierzy (s. 34). }\end{array}$ \\
\hline $1,3,5,7$ & 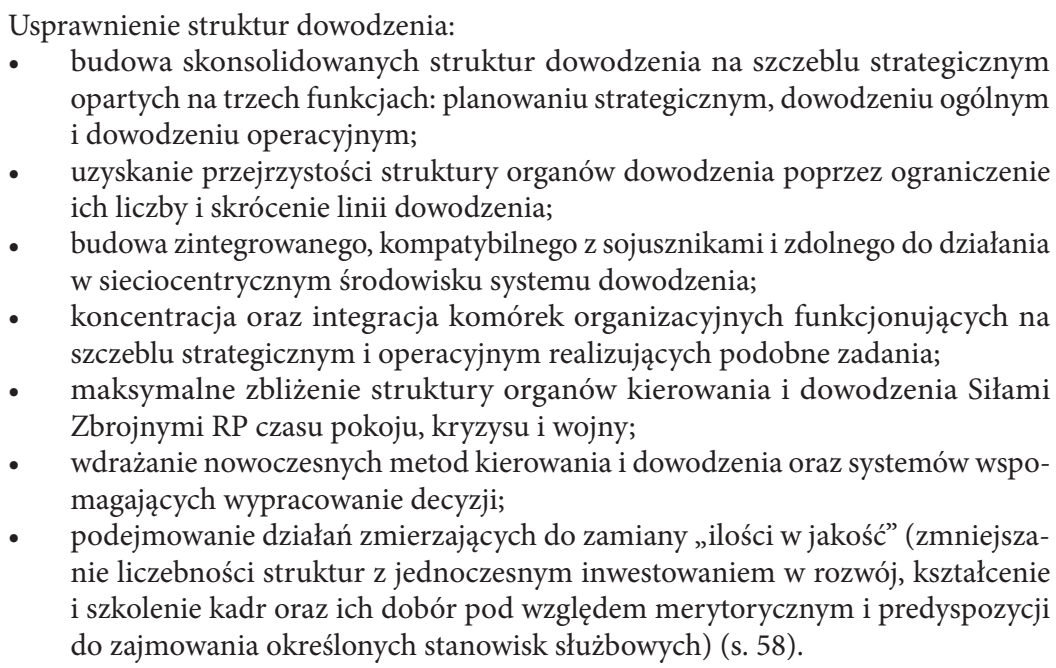 \\
\hline 3,4 & $\begin{array}{l}\text { Podnoszenie poziomu wykształcenia i kształcenia zawodowego żołnierzy poprzez } \\
\text { kontynuowanie realizacji przedsięwzięć ujętych w corocznych planach doskonalenia } \\
\text { zawodowego żołnierzy Sił Zbrojnych RP oraz planach kształcenia i egzaminowania } \\
\text { ze znajomości języków obcych w resorcie obrony narodowej. }\end{array}$ \\
\hline $3,4,5,7$ & $\begin{array}{l}\text { Podnoszenie poziomu wyszkolenia wojsk i doskonalenie zawodowe żołnierzy za- } \\
\text { wodowych, osiąganie zdolności do dowodzenia podległymi wojskami przy pełnym } \\
\text { wykorzystaniu możliwości zautomatyzowanych systemów dowodzenia: } \\
\text { - } \quad \text { ukierunkowywanie szkolenia organów dowodzenia na zgrywanie systemów walki; } \\
\text { - } \quad \text { doskonalenie nowego trzyletniego modelu szkolenia wojsk; } \\
\text { - } \quad \text { pozyskiwanie i wdrażanie nowoczesnych, zintegrowanych systemów szkolenia; } \\
\text { NATOtowanie komponentów Sił Zbrojnych RP wydzielanych do Sił Odpowiedzi } \\
\text { - } \quad \text { korzystanie z sojuszniczych ośrodków szkoleniowych i centrów doskonalenia; } \\
\text { - doskonalenie działalności szkoleniowo-metodycznej centrów i ośrodków szko- } \\
\text { lenia; } \\
\text { doskonalenie współdziałania między siłami zbrojnymi a elementami pozamilitar- } \\
\text { nych struktur obronnych państwa, szczególnie w zakresie reagowania kryzysowego } \\
\text { oraz w obronie przed terroryzmem; }\end{array}$ \\
\hline
\end{tabular}




\begin{tabular}{|c|c|}
\hline $\begin{array}{c}\text { Numer } \\
\text { kluczowej } \\
\text { kompetencji }\end{array}$ & $\begin{array}{l}\text { Wyróżniki strategiczne odnoszące się do kapitału ludzkiego } \\
\text { w Strategii bezpieczeństwa narodowego Rzeczypospolitej Polskiej }\end{array}$ \\
\hline $3,4,5,7$ & $\begin{array}{l}\text { - zwiększanie efektywności szkolenia poprzez wykorzystywanie nowoczesnych } \\
\text { narzędzi symulacyjnych, w tym m.in. wprowadzenie systemu szkolenia z uży- } \\
\text { ciem sieci komputerowych (e-learning) oraz tworzenie ośrodków szkolenia } \\
\text { symulacyjnego; } \\
\text { rozszerzenie zakresu wykorzystania symulatorów i innych urządzeń treningowych, } \\
\text { opartych na nowoczesnych technologiach; } \\
\text { przygotowywanie organów dowodzenia do realizacji zadań w środowisku sie- } \\
\text { ciocentrycznym; } \\
\text { dostosowywanie do wymagań rozwojowych (wprowadzanej techniki i technologii) } \\
\text { obiektów i urządzeń szkolno-treningowych zapewniających realizację szkolenia } \\
\text { przy zachowaniu jego realizmu i racjonalności kosztów; } \\
\text { wdrażanie do Sił Zbrojnych RP wraz z nowym uzbrojeniem i sprzętem woj- } \\
\text { skowym pakietów szkoleniowych stanowiących pełne zabezpieczenie w środki } \\
\text { dydaktyczne, służące kształceniu i szkoleniu stanów osobowych Sił Zbrojnych RP. }\end{array}$ \\
\hline $3,5,7$ & $\begin{array}{l}\text { Rozwijanie i wdrażanie innowacyjnych koncepcji i doktryn, centralizacja zarządzania } \\
\text { procesem standaryzacji operacyjnej i opracowywania doktryn, dokumentów dok- } \\
\text { trynalnych w ramach funkcjonowania Centrum Doktryn i Szkolenia Sił Zbrojnych: } \\
\text { - } \quad \text { opracowywanie projektów doktryn i dokumentów doktrynalnych przez } \\
\text { Centrum Doktryn i Szkolenia Sił Zbrojnych (stosownie do zmian zachodzących } \\
\text { w Sojuszu i potrzeb Sił Zbrojnych RP) oraz ich implementacja; } \\
\text { - udział w pracach rad, grup i paneli roboczych KW NATO i UE w obszarze } \\
\text { standaryzacji operacyjnej; } \\
\text { - wypracowywanie nowych koncepcji i sposobów prowadzenia działań i or- } \\
\text { ganizacji szkolenia oraz ich weryfikowanie poprzez eksperymentowanie; } \\
\text { - współpraca Centrum Doktryn i Szkolenia Sił Zbrojnych z podobnymi pod } \\
\text { względem kompetencji instytucjami NATO, UE, państw członkowskich Sojuszu } \\
\text { i innych państw. }\end{array}$ \\
\hline $7,8,9$ & $\begin{array}{l}\text { Wdrożenie Systemu Wykorzystania Doświadczeń z działalności Sił Zbrojnych RP: } \\
\text { - doskonalenie Systemu Wykorzystania Doświadczeń w Siłach Zbrojnych } \\
\text { RP, opartego na jednolitym i uniwersalnym procesie wykorzystywania doświadczeń, } \\
\text { etatowych strukturach systemu (Centrum Doktryn i Szkolenia Sił Zbrojnych) oraz } \\
\text { profesjonalne przygotowanie personelu; } \\
\text { - rozwijanie procesu wykorzystania doświadczeń, obejmującego etapy: iden- } \\
\text { tyfikacji i obserwacji; analizy; zatwierdzania działań naprawczych i stawiania zadań; } \\
\text { wdrażania i monitoringu; weryfikacji - określenia skuteczności działań naprawczych; } \\
\text { - rozwijanie specjalistycznego systemu informatycznego oraz odpowiedniego } \\
\text { aparatu pojęciowego, wspierającego funkcjonowanie systemu wykorzystania doświad- } \\
\text { czeń w Siłach Zbrojnych RP. }\end{array}$ \\
\hline
\end{tabular}

Źródło: opracowanie własne

Jak wynika z przeprowadzonej analizy, najwięcej wskazań (10) dotyczyło kompetencji nr 3 - „rozwijanie know-how pracowników - stwarzanie warunków sprzyjających kreatywności pracowników, co równocześnie wzbogaca ich pracę". Na drugim miejscu znalazły się dwie kompetencje, a mianowicie nr: 7 i 9 (każda po 6 wskazań). Kompetencja nr 7 odnosi się do „stymulowania procesu 
uczenia się przedsiębiorstwa i działania zgodnego z ustrukturyzowanymi procesami rozwiązywania problemów oraz stwarzania warunków do pracy zespołowej, która sprzyja uczeniu się przedsiębiorstwa”. Z kolei kompetencja nr 9 dotyczy „budowania reputacji przedsiębiorstwa oraz dbałości o pozytywne relacje z klientami, dostawcami, kontrahentami i pracownikami, a także stwarzania warunków do osiągania wysokiej efektywności”.

Najmniej wskazań (1) dotyczyło: kompetencji nr 1 - przywództwo, która obejmuje umiejętności przełożonych do artykułowania i komunikowania wizji oraz budowania strategii przedsiębiorstwa, a także wspierania podwładnych w realizacji zadań, kompetencji nr 2 - „wykorzystanie otoczenia przedsiębiorstwa - koncentracja na kliencie i dostarczanie informacji o otoczeniu”, kompetencji nr 6 - „zaangażowanie na rzecz przedsiębiorstwa - realizowanie przedsięwzięć sprzyjających identyfikacji z celami i wartościami uznawanymi w przedsiębiorstwie za ważne”.

\section{Podsumowanie}

Rezultaty przeprowadzonej analizy wskazują na zdecydowaną zmianę w postrzeganiu kluczowych kompetencji organizacyjnych dotyczących kapitału ludzkiego Sił Zbrojnych RP. Globalizacja oraz rosnąca konkurencja w skali krajowej i międzynarodowej również wymagają nowego podejścia do praktyk i zadań związanych z zarządzaniem kapitałem ludzkim w wojsku. Praktyczne wyzwania w tym zakresie związane są z:

- jakościową zmianą konfliktów, przejściem od konfliktów konwencjonalnych do zagrożeń asymetrycznych,

- wymogiem budowania kapitału relacyjnego na bazie stosunków dyplomatycznych i sojuszy (wspólne misje i ćwiczenia).

Dotychczasowe kluczowe kompetencje wynikają ze specyfiki procesu zarządzania w wojsku zdeterminowanego rodzajem realizowanych zadań oraz cechami struktury organizacyjnej, w szczególności: hierarchiczną strukturą opartą na autorytecie dowódcy, etosem służby krajowi oraz bardzo dobrym przygotowaniem organizacyjno-logistycznym działań. Kompetencje te wymagają uzupełnienia o nowe, odzwierciedlające złożoność świata (procesów społecznych, gospodarczych, technicznych i technologicznych). Wymusza to oparcie działań Sił Zbrojnych RP na wiedzy, rozwoju nowych umiejętności i budowaniu relacji z interesariuszami przy zachowaniu ich wysokiej efektywności. W zarządzaniu kapitałem ludzkim w Siłach Zbrojnych RP należy rozważyć podejście bazujące na kluczowych kompetencjach organizacyjnych, które odzwierciedlają złożoność obecnego świata, w tym gospodarki. Na dalszy plan powinny natomiast zostać przesunięte kompetencje wynikające z hierarchicznej struktury wojska. Nowe kompetencje kluczowe powinny 
obejmować zarządzanie wiedzą, rozwój nowych technologii i budowanie relacji z interesariuszami przy zachowaniu wysokiej efektywności działań Sił Zbrojnych. Jednocześnie warto podkreślić, że mimo braku wyeksponowania $\mathrm{w}$ dokumentach strategicznych zapisów dotyczących kompetencji nr 2, „wykorzystania otoczenia przedsiębiorstwa", w tym zwrócenia szczególnej uwagi na klienta - jednostki wojskowe intensywnie współpracują z organizacjami pozarządowymi oraz partnerami społecznymi. Podstawą tej współpracy są zapisy Decyzji Ministra Obrony Narodowej określające cele, zasady i formy współpracy: Nr 187 z dnia 9 czerwca 2009 roku Zasady wspótpracy resortu obrony narodowej z organizacjami pozarządowymi i innymi partnerami społecznymi, DzUrz MON z 2009, Nr 12, poz. 131; Nr 146 z dnia 11 kwietnia 2011 r. zmieniającej decyzję w sprawie wprowadzenia zasad wspótpracy resortu obrony narodowej $z$ organizacjami pozarzadowymi i innymi partnerami społecznymi, DzUrz MON z 2011, Nr 9, poz. 121, a także Nr 396/MON z dnia 18 grudnia 2013 r. zmieniającej decyzję w sprawie wprowadzenia zasad współpracy resortu obrony narodowej $z$ organizacjami pozarzadowymi i innymi partnerami społecznymi, DzUrz MON z 2013, poz. 347. W decyzji jako cele współpracy wojska z organizacjami pozarządowymi i partnerami społecznymi wskazuje się zwiększenie zaangażowania obywateli w działania na rzecz obronności państwa oraz edukację obronną społeczeństwa, w szczególności: pozyskiwanie społecznej akceptacji dla polityki obronnej państwa; upowszechnianie działalności wolontariackiej na rzecz obrony narodowej; kształtowanie pozytywnego wizerunku Sił Zbrojnych i służby wojskowej, promowanie nowego modelu służby żołnierzy rezerwy w Narodowych Siłach Rezerwowych.

Duże zainteresowanie współpracą obywateli z wojskiem można zaobserwować m.in. na przykładzie Dowództwa Generalnego Rodzajów Sił Zbrojnych i podległych mu jednostek wojskowych. W 2014 roku liczba porozumień o współpracy wyniosła 720 , zaś w 2015 roku -- 883 (wzrost o 22,6\% w stosunku do roku ubiegłego) ${ }^{2}$. Wojsko współpracowało zarówno z organizacjami reprezentującymi sektor publiczny, jak i prywatny (w tym organizacjami pracodawców, izbami gospodarczymi i rzemieślniczymi). W latach 2014-2015 jednostki wojskowe podpisały porozumienia o współpracy z: uczelniami wyższymi, szkołami, władzami samorządowymi, fundacjami i stowarzyszeniami, a także klubami sportowymi. Do najczęstszych form współpracy należało: organizacyjne i koncepcyjne wsparcie przedsięwzięć, udostępnianie pomieszczeń, asysta wojskowa oraz udostępnianie sprzętu wojskowego (Piotrowska-Trybull, 2016, s. 306-321). Ogólna ocena współpracy wymienionych

2 Informacja o wynikach wspótpracy Dowództwa Generalnego Rodzajów Sił Zbrojnych i podlegtych jednostek wojskowych z partnerami społecznymi w 2014 r., DG RSZ, Załącznik 1, marzec 2015, s. 17-18; Informacja o wynikach współpracy Dowództwa Generalnego Rodzajów Sit Zbrojnych i podległych jednostek wojskowych z partnerami społecznymi w 2015 r., DG RSZ, Załącznik 1, marzec 2016, s. 22. 
podmiotów z wojskiem jest pozytywna, jednak pojawiają się pewne trudności. Wynikają one z jednej strony ze wzmożonej aktywności partnerów społecznych i organizacji pozarządowych zgłaszających chęć współpracy z wojskiem, co przy braku wystarczających zasobów powoduje zakłócenia w działalności służbowej jednostek, z drugiej zaś z braku zapisów strategicznych i rozwiązań organizacyjnych, które nadałyby odpowiednią rangę współpracy i umożliwiły sprawniejszy jej przebieg.

Odnosząc się do „wykorzystania otoczenia przedsiębiorstwa” na rzecz wzmocnienia kompetencji kapitału ludzkiego w Siłach Zbrojnych RP, można wskazać, że współpraca wojska ze społeczeństwem przynosi określone korzyści. Dowodem tego są pozytywne oceny funkcjonowania wojska wyrażone przez $69 \%$ respondentów uczestniczących w badaniach CBOS we wrześniu 2015 roku (Oceny instytucji publicznych, 2015, s. 11).

\section{LITERATURA}

[1] Allaire Y., Firsirotu M.E., Myślenie strategiczne, PWN, Warszawa 2000.

[2] BARUK J., Innowacje instrumentem zarządzania przedsiębiorstwem, [w:] A. Kaleta, K. Moszkowicz, L. Woźniak (red.), Przedsiębiorczość i innowacyjność. Wyzwania współczesności, „Prace Naukowe Akademii Ekonomicznej im. Oskara Langego we Wrocławiu”, AE, Wrocław 2006.

[3] Bednaczyк M., Organizacje publiczne. Zarządzanie konkurencyjnościa, WN PWN, WarszawaKraków 2001, [za:] B. Kożuch, 2003, Zarządzanie publiczne w zarysie, Fundacja Współczesne Zarządzanie, Białystok 2001.

[4] BLACK J., Słownik ekonomii, PWN, Warszawa 2008.

[5] BRATNicki M., Kompetencje przedsiębiorstwa, od określenia kompetencji do zbudowania strategii, Placet, Warszawa 2000.

[6] Edvinsson L., Malone M., Intellectual Capital: The Proven Way to Establish Your Company's Real Value By Measuring Its Hidden Brainpower, Piatkus, London 1997.

[7] GRIfFIn R.F., Podstawy zarządzania organizacjami, PWN, Warszawa 2002.

[8] Hamel G., Prahalad C.K., Strategic intent, „Harvard Business Review”, May-June nr 3, 1989.

[9] Hamel G., Prahalad C.K., The core competence of the Corporation, „Harvard Business Review”, nr 3, 1990.

[10] Informacja o wynikach współpracy Dowództwa Generalnego Rodzajów Sił Zbrojnych i podległych jednostek wojskowych z partnerami społecznymi w 2014 r., DG RSZ, Załącznik 1, marzec 2015.

[11] Informacja o wynikach wspótpracy Dowództwa Generalnego Rodzajów Sił Zbrojnych i podległych jednostek wojskowych z partnerami społecznymi w 2015 r., DG RSZ, Załącznik 1, marzec 2016.

[12] Kossek E.E., The acceptance of human resource innovation by multiple constituencies, „Personnel Psychology" nr 42, [za:] M. Staniewski, 2011, Innowacyjne zarządzanie zasobami ludzkimi w polskich przedsiębiorstwach, Studia BAS, nr 1(25), 1989.

[13] Król H., Ludwiczyński A., Zarządzanie zasobami ludzkimi. Tworzenie kapitału ludzkiego organizacji, PWN, Warszawa 2006.

[14] Kuriata R., Bezpieczeństwo narodowe - podstawowe kategorie i ich systematyzacja teoretyczna, [w:] A. Dębska (red.), Bezpieczeństwo społeczne w systemie bezpieczeństwa narodowego, Naukowe Wydawnictwo Piotrkowskie, 2016. 
[15] Mazurkiewicz A., FrączeK P., Kluczowe kompetencje a konkurencyjność przedsiębiorstw, „Nierówności Społeczne a Wzrost Gospodarczy" nr 20, Uniwersytet Rzeszowski, [za:] M. Łoboda, A. Sitko-Lutek, 2007, Kompetencje i luka kompetencyjna organizacji, [w:] A. Sitko-Lutek (red.), Polskie firmy wobec globalizacji. Luka kompetencyjna, PWN, Warszawa 2011.

[16] Nowakowska-Krystman A., Piotrowska-Trybull M., Przemiany w Siłach Zbrojnych w kontekście współczesnych koncepcji zarządzania, [w:] K. Krukowski, S. Sasak (red.), Tendencje we współczesnym zarzq̨dzaniu publicznym, [w:] „Studia i Monografie”, Instytut Spraw Publicznych UJ, Kraków 2016.

[17] Oceny instytucji publicznych, Komunikat z badań, Nr 131/2015, CBOS, Warszawa.

[18] Penc J., Innowacje i zmiany w firmie. Transformacja i sterowanie rozwojem przedsiębiorstwa, Agencja Wydawnicza Placet, Warszawa 1999.

[19] Piotrowska-Trybull M., Współpraca jednostek wojskowych z organizacjami pozarządowymi i partnerami społecznymi na przykładzie Dowództwa Generalnego Rodzajów Sił Zbrojnych, [w:] T. Majewski, M. Piotrowska-Trybull, S. Sirko (red.), Współczesne wyzwania dla dowodzenia i zarządzania, Wyd. Adam Marszałek, Toruń 2016.

[20] Samul J., Definicje kapitału ludzkiego w ujęciu porównawczym, „Zeszyty Naukowe Uniwersytetu Przyrodniczo-Humanistycznego w Siedlcach", nr 96, 2013.

[21] Schumpeter J., Teorie rozwoju gospodarczego, PWN, Warszawa 1960.

[22] StawASz E., NiedBALSKa G., http://www.pi.gov.pl/parp/chapter_96055.asp?soid=040D4787179 74D15A8EC2406EE3A3E1D (29.11.2016).

[23] Strategia bezpieczeństwa narodowego Rzeczypospolitej Polskiej, Rada Ministrów w 2014 r.

[24] Strategia rozwoju systemu bezpieczeństwa narodowego Rzeczypospolitej Polskiej, Rada Ministrów $\mathrm{z}$ dnia 9 kwietnia $2013 \mathrm{r}$. 
